\title{
Çanakkale Halk Bahçesi'nin Herkes için Tasarım İlkeleri Açısından İrdelenmesi
}

\author{
Alper SAĞLIK ${ }^{1 *}$, Sena DEMİR ${ }^{2}$, Rozerin ÇELIK ${ }^{2}$, Orazgeldi DURDYMYRADOV ${ }^{2}$, Mehmet \\ İlkan BAYRAK ${ }^{3}$ \\ 1,3 Çanakkale Onsekiz Mart Üniversitesi, Mimarlık ve Tasarım Fakültesi, Peyzaj Mimarlığı Bölümü, 17100, \\ ÇANAKKALE. \\ ${ }^{2}$ Çanakkale Onsekiz Mart Üniversitesi, Fen Bilimleri Enstitüsü, Peyzaj Mimarlığı Anabilim Dalı, 17100, \\ ÇANAKKALE.
}

\section{Öz}

Kentsel mekânlar kullanıcının gün içinde rekreasyonel faaliyetlerini gerçekleştirdikleri mekânlardır. Bu mekânlardan kentsel parklar barındırdıkları açık yeşil alan ve donatı elemanları ile bireyleri fiziksel ve psikolojik açıdan olumlu etkilemektedir. Fakat her kullanıcı aynı niteliklere sahip değildir. Kent içinde oldukça öneme sahip olan kent parklarının tasarımında dezavantajlı kullanıcılar da göz önüne alınmalıdır. Bu çalışma kapsamında kentsel dış mekânlarda herkes için tasarım örnekleri incelenmiş ve Çanakkale'deki kent parklarından Halk Bahçesi'nin durum tespiti yapılıp eksiklikleri saptanmıştır. Çalışma sonucunda, kentsel dış mekânların tüm kullanıcılar tarafından işlevsel kullanımı Evrensel Tasarım Merkezi'nin ortaya koyduğu 7 ilke doğrultusunda irdelenmiş, konu dâhilinde literatürde saptanan eksikliklere ışık tutacağ düşünülmüştür. Bu bağlamda Çanakkale Halk Bahçesi’ne yönelik herkes için tasarım önerileri geliştirilmiştir.

Anahtar Kelimeler: Herkes için tasarım, kent park, tasarım.

\section{Investigation of Çanakkale Public Garden In Terms of Design Principles For Everyone}

\begin{abstract}
Urban spaces are the places where the user performs their recreational activities during the day. Urban parks, which are among these places, affect individuals physically and psychologically with their open green areas and equipment elements. But not every user has the same qualifications. Disadvantaged users should also be considered in the design of urban parks, which are of great importance in the city. Within the scope of this study, design examples for everyone in urban outdoor spaces were examined and the situation of the Public Garden, one of the urban parks in Çanakkale, was determined and its deficiencies were determined. As a result of the study, the functional use of urban outdoor spaces by all users was examined in line with the 7 principles put forward by the Universal Design Center, and it was thought that it would shed light on the deficiencies identified in the literature. In this context, design suggestions have been developed for the Çanakkale Public Garden for everyone.
\end{abstract}

Keywords: Design for everyone, urban park, design

\footnotetext{
*Sorumlu Yazar (Corresponding Author): 


\section{Giriş}

Yaşadığımız çevreyi oluşturan kentsel mekânların barındırdığı yeşil alanlar, farklı büyüklüklerde bulunmakla birlikte birçok işleve sahip alanlardır. Kentteki yeşil dokunun büyük çoğunluğunu oluşturan kent parkları, genel olarak hitap ettiği kullanıcı kitlesinin ihtiyaç ve gereksinimlerini karşılamak üzere tasarlanır. Kentlilerin bu alanlarda rekreasyonel faaliyetlerini gerçekleştirebilmeleri için oturma birimleri, spor aletleri, çocuk oyun ekipmanları gibi birtakım donatı elemanları bulundurulur. Kent parklarının biyoçeşitlilik bakımından zengin olması bulunduğu bölgenin ekosistemine ve yeşil dokusuna katkı sağlamaktadır. Bu durum kentlinin yaşam standartlarının da yükseltilmesini sağlar. İlk zamanlarda genellikle dönemin şartlarına uygun olarak avlanmak için kullanılan kent parklarının kullanımı zamanla değişim göstererek farklı amaçlar için kullanılmaya başlanmıştır. Olmsted'in arayıcılığıyla esas anlamı olan kent parkları yapısına yükseltilmiştir. Kent parkları tarihi incelendiğinde ise 1536 yıllarında insanların avlanmak için kullandıkları alan olarak karşımıza çıkmaktadır. Henry Vills tarafından Londra'da tasarlanan Hyde Park ve peyzaj mimarlığının babası olarak anılan Olmsted'in Central Park'ına kadar günümüze kadar ulaşan örnekler kent parkı kullanımlarının değişimini gözler önüne sermektedir (URL 1, 2015).

Kent parklarının tasarımı planlanırken tüm yıl boyunca kullanılabilir nitelikte olmasına dikkat edilmelidir. Kış aylarındaki soğuk, rüzgâr, nem ve yaz aylarındaki güneş ve sıcaklık kentsel alanlarda bulunan donatıları büyük oranda etkilemektedir (Çetin, 2003; Ünal, 2009). Çanakkale gibi kıyı şehirleri için rüzgâr, tasarımı ve dolayısıyla kentsel mekânlardan biri olan parkları etkileyen en önemli unsurlardan biridir. Yapılacak tasarımlar buna göre konumlandırılmadır.

Kentlinin ortak kullanım alanları olan kentsel parklar her kullanıcıya hitap edecek şekilde tasarlanmalıdır (Nemutlu vd., 2018). Kent içinde bulunan her kullanıcı aynı özelliklere sahip değildir. Dezavantajlı kullanıcılar da bulunmaktadır. Mekân ve mekânı oluşturan donatılara; yaşlılar, çocuklar, yabancı turistler ve engelli bireyler için de erişim olanağı sağlanmalıdır. Bu erişim sağlanırken yapıların özgün karakteri korunarak zarar verilmemeli ve çevre herkesin kullanımına uygun hale getirilmelidir (Çenet, 2013).

Söz konusu dezavantajlı kullanıcıların yolları ve girişleri rahatlıkla kullanabilmesi için tasarım kriterleri bulunmaktadır ve bu yolların belirlenen standartlara uygun tasarlanması gerekir (Nemutlu vd., 2018). Bu kriterler Evrensel Tasarım Merkezi (The Center for Universal Design) tarafindan belirlenmiştir ve 7 ilkeden oluşur (Ergenoğlu, 2013). Tüm çevresel etmenler ve donatı elemanları bu kapsamda değerlendirilmeli ve dezavantajlı gruba giren tüm bireylerin dış mekânlarda yaşadıkları erişim sorunları göz önünde bulundurularak tasarımlar gerçekleştirilmelidir.

$\mathrm{Bu}$ çalışmada günümüzde tasarlanan kentsel açık alanların kullanıcı için önemi vurgulanarak, dezavantajlı kullanıcılar için de kullanım olanaklarının olması esasında yapılması gereken tasarım ilkeleri ortaya konulmuştur. Kullanıcıların alanlara erişilebilirliği sağlanarak toplumda her kesimden kullanıcının vakit geçireceği güvenli mekânlar oluşturulmasında yol göstermek amacıyla yürütülen bir çalışmadır. Çalışmada evrensel tasarım anlayışında belirlenen 7 ilke çerçevesinde kentsel park tasarımının irdelenmesi amaçlanmıştır. Özellikle dezavantajlı bireylerin erişimi düşünülerek dış mekânlarda rahatlıkla vakit geçirip bir engelle karşılaşmadan rekreasyonel ihtiyaçlarını karşılamaları hedeflenmiştir. Söz konusu 7 ilke aşağıda belirtildiği gibidir (Ergenoğlu, 2013):

1. Illke: Eşit Kullanım: Tasarım tüm kullanıcılar için aynı kullanım hakkını sağlamalı; aynı değilse bile eşdeğer imkân sunulmalıdır.

2. Ilke: Kullanımda Esneklik: Tasarımda bireylerin yetenekleri doğrultusunda kullanım olanakları sağlanmalıdır.

3. Ilke: Basit ve Sezgisel Kullanım: Tasarımın kullanımında kullanıcının rahat algılaması için karmaşıklıktan uzak durulmalıdır.

4. Ilke: Algılanabilir Bilgi: Tasarım gerekli bilgiyi mekânı tanımlamada farklı anlatımlarla aktarmalıdır.

5. Ilke: Hatalara Dayanım: Kullanım öğelerindeki tehlike ve kaza riski tüm kullanıcılara yönelik en aza indirilmelidir.

6. Illke: Düşük Fiziksel Çaba: Tasarımın en az güçle kullanıcının doğal pozisyonunu bozmayacak şekilde kullanımı sağlanmalıdır.

7. Illke: Yaklaşım ve Kullanım İçin Boyut ve Mekân: Tasarım her türlü kullanıcının ergonomik formuna uygun olmalıdır.

Çalışma alanı olarak Çanakkale merkez bölgesinde bulunan kentin yeşil alanının büyük kısmını barındıran Halk Bahçesi belirlenmiştir. Bu bölgenin seçilmesinin en önemli nedeni kentlinin aktif kullandığı bir dinlenim alanı olması ve alanın yerleşim yerleri arasında erişilebilir bir durumda olmasıdır. 


\section{Materyal ve Metot}

\subsection{Materyal}

Araştırma alanını kapsayan Çanakkale, $25^{\circ} 40^{\prime}-27^{\circ} 30^{\prime}$ doğu boylamları ve $39^{\circ} 27^{\prime}-40^{\circ} 45^{\prime}$ kuzey enlemleri arasında 9.933 km2'lik bir alandır. Çanakkale ilinin çevre komşuları Balıkesir, Edirne ve Tekirdağ'dır. İlin Ege ve Marmara Bölgesinde toprakları bulunmaktadır ve kıyı uzunluğu 671 kilometredir (URL 2, 2021) (Şekil 1).
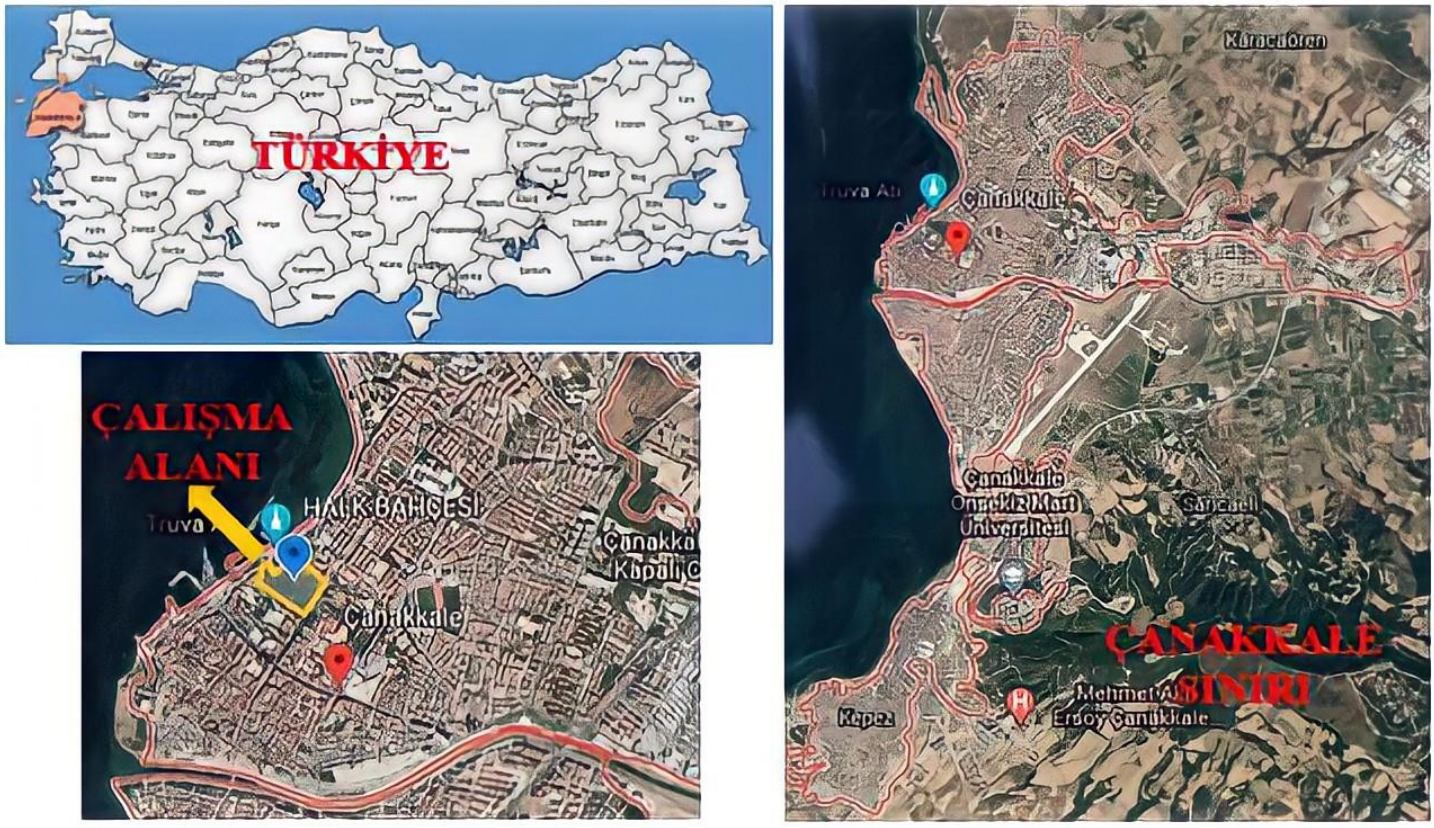

Şekil 1. Çalı̧̧ma alanının konumu (Google Earth, 2021; URL 3, 2020).

Çalışma ana materyalini Çanakkale kent merkezine bağlı Halk Bahçesi oluşturmaktadır. Kentte kullanımı en yoğun alanlar içinde olan Halk Bahçesi Calvert ailesine ait olan konağın bahçesinden geri kalan bir bölümdür (URL 4, 2008; Erduran ve Kabaş, 2010) (Şekil 2).
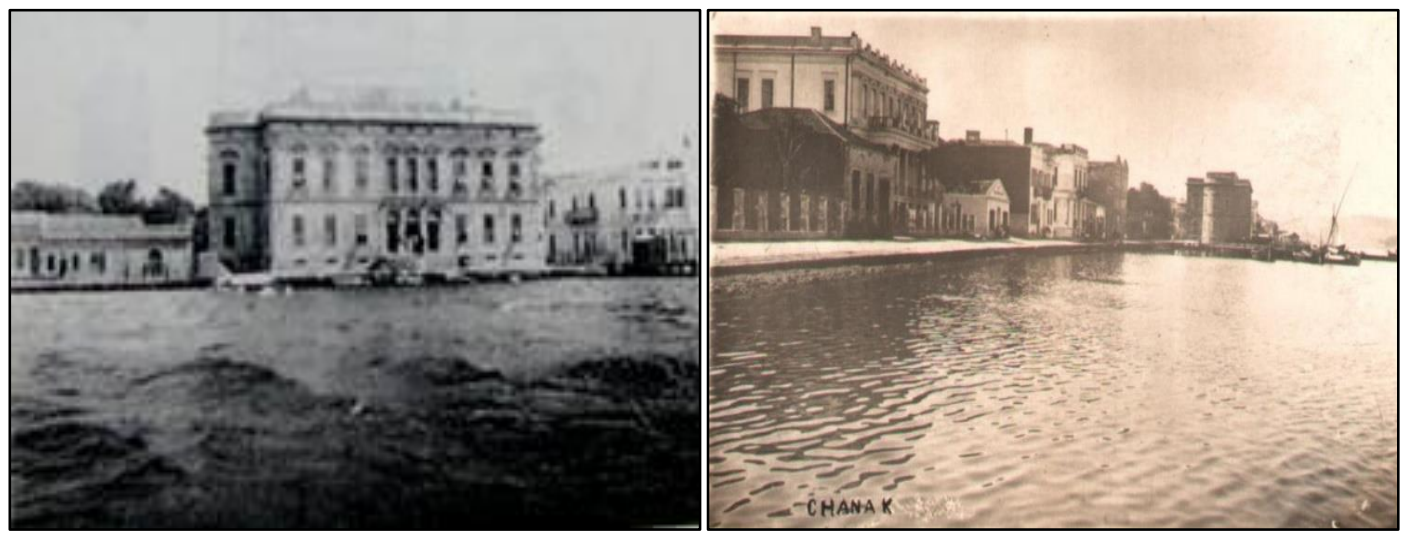

Şekil 2. Çalışma alanının kamusallaştırılmadan önceki hali (URL 5, 2012).

Çalışmanın diğer materyallerini ise Çanakkale kentinde bulunan Halk Bahçesi kent parkına ait çekilen fotoğraflar, yerinde tutulan gözlem notları ve belediyeden temin edilen imar planı oluşturmaktadır (Şekil 3). 


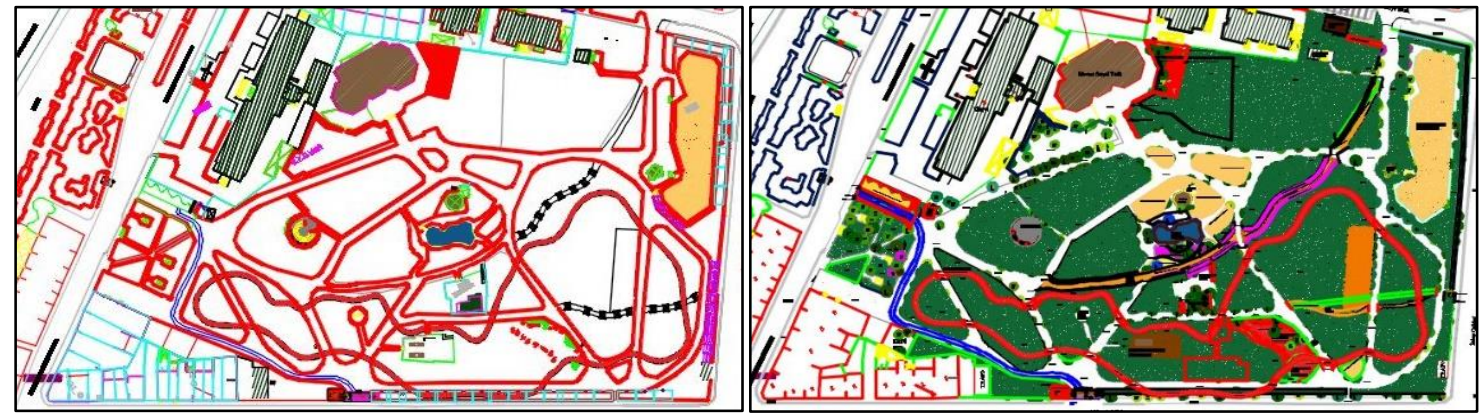

Şekil 3. Yapısal ve bitkisel planlar (Çanakkale Belediyesi, 2021).

\subsection{Metot}

Çalışma konusu kapsamında literatürdeki araştırmaların yöntemini incelemeler, yerinde gözlemler, alan analizleri oluşturmaktadır. Betimsel analizler sonucunda tasarım önerileri geliştirilmektedir. Bu bağlamda araştırma yöntemi geliştirilirken; Çelik (2013), Çenet (2013), Hatipoğlu (2017), Kuter ve Çakmak (2017), Demirci (2020), İmren ve Kiper (2020)'in yürüttüğü çalışmalardan yararlanılmıştır. Bu doğrultuda;

- Çalışmada yöntemsel olarak; Halk Bahçesi’nde herkesin kullanımına olanak sağlayacak şekilde kentsel tasarım öğeleri incelenmiş ve yerinde gözlemler yapılmıştır. Alan içinde belirlenen peyzaj öğelerinin olumlu ve olumsuz yönde analizi oluşturularak, herkes için tasarım kapsamında tasarım önerileri geliştirilmiştir.

- Çalışma yönteminde literatür taraması ile beraber alan araştırması yapılmıştır. Yerinde gözlem yapılarak elde edilen bilgiler not alma tekniği ile kaydedilerek analiz edilmişstir. Bu kapsamda alan üzerinde tasarım süreçleri irdelenmiştir.

- Bu çalışma nitel araştırma yöntemlerinden betimsel analiz yoluyla yerinde gözlem yapılarak mevcut sorunların tespitini kapsamaktadır (Çenet, 2013).

Çalışma 5 aşamadan oluşmaktadır (Sağlık vd., 2016; Hatipoğlu, 2017):

1.aşama: Çalışmanın kapsamı ve içeriği belirlenmiştir. Çalışma alanı olarak Çanakkale Halk Bahçesi belirlenmiştir. Alan içinde bulunan canlı-cansız peyzaj elemanlarının evrensel tasarım ilkeleri kapsamında incelenmesi gerçekleştirilmiştir.

2. aşama: Alana ve konuya ilişkin veri toplama ile literatür taraması yapılmıştır. Dünya çapında evrensel tasarım ilkeleri doğrultusunda gerçekleştirilen tasarımlar irdelenmiştir. İhtiyaç duyulan veriler ve vaziyet planı Çanakkale Belediyesi'nden temin edilmiştir.

3. aşama: Yöntem uygulanmıştır. Halk Bahçesi'nde bulunan peyzaj elemanları çalışma konusu kapsamında tespit edilmiş ve evrensel tasarım ilkelerine uygunluğu değerlendirilmiştir. Değerlendirmeler sonucu peyzaj elemanlarının hangi yönleri ile kriterlere uygun oldukları ya da olmadıkları belirlenmiştir.

4. aşama: Değerlendirme aşamasına geçilmiştir. Alanda yerinde gözlem ve incelemelerle fotoğraflandırma yapılmıştır. Dijitale aktarılan fotoğraflar not alma tekniği ve görsel analizle değerlendirilmiştir.

5. aşama: Belirlenen sonuç doğrultusunda alana ilişkin tasarım önerileri geliştirilmiştir.

Araştırmada elde edilen bulgular doğrultusunda kullanıcının ihtiyaçlarını belirleyip karşılaşabileceği olumsuz etmenler ve çözüm önerileri için evrensel tasarım ilkeleri kapsamında literatür taraması yapılmıştır ve evrensel tasarım yaklaşımı ile çalışma alanı değerlendirilmiştir. Elde edilen veriler ışığında alan kullanım haritası, fotoğraflandırma, gözlem yoluyla sorunlar tespit edilmeye çalışılmıştır (Şekil 4). 


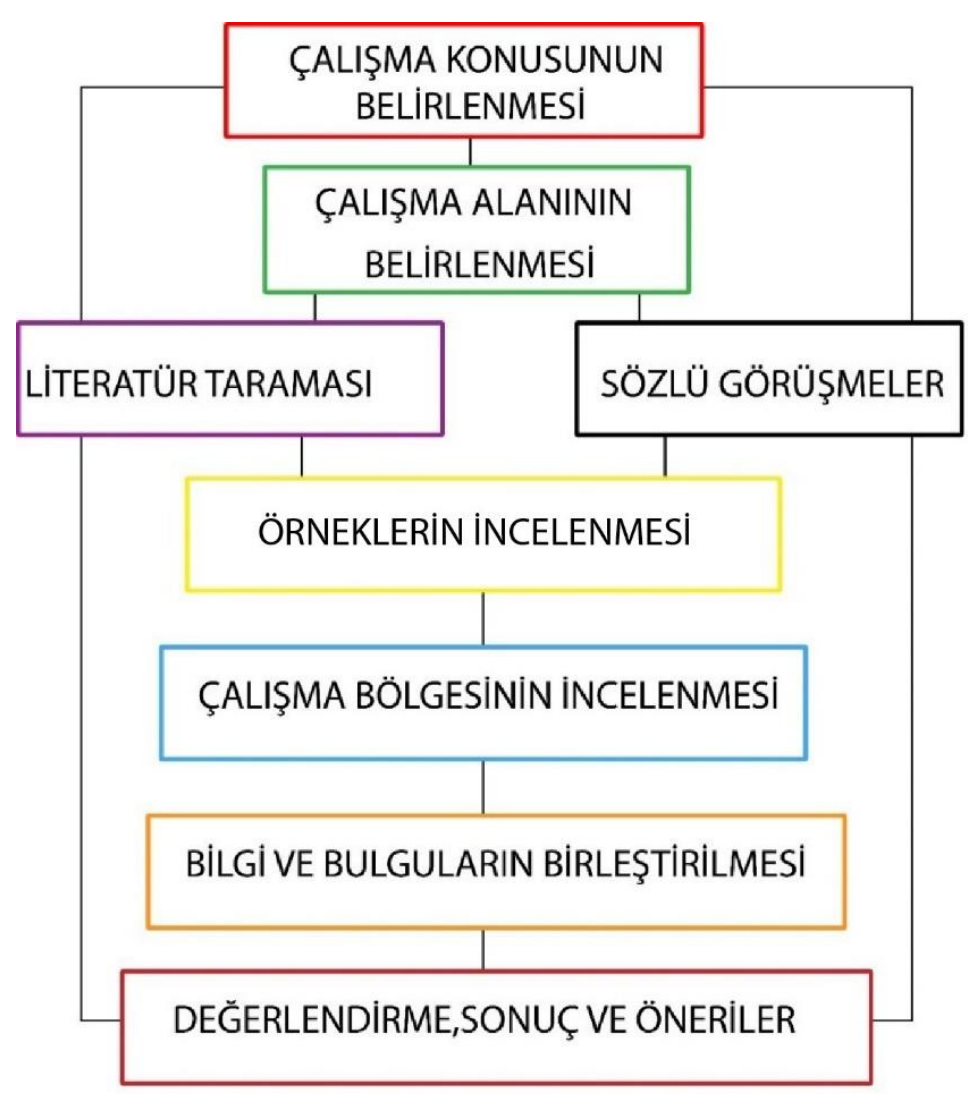

Şekil 4. Çalışmanın akış diyagramı (Sağlık vd, 2016; Hatipoğlu, 2017)

\section{Bulgular ve Tartışma}

Çalışma alanı olan Çanakkale Halk Bahçesi, Calvert Bahçesi veya İngiliz Bahçesi olarak bilinmektedir. 36.500 m2 büyüklüğündeki bu alan 1938 yılında kamusallaştırılarak parka dönüştürülmüştür. Halk Bahçesinde bulunan bitkiler çoğunlukla geniş yapraklı ağaç ve çalılardan oluşmaktadır. Alanda benzer türden bitkilere sıklıkla rastlanmaktadır. Genellikle Ulmus campestris L., Fraxinus excelsior L., Pinus brutia L., Cupressus sempervirens L., Laurus nobilis L. bitki türlerine rastlanmaktadır. Mevcut bitkiler seçilirken Anadolu ve Akdeniz ikliminde gelişim gösteren türler tercih edilmiştir (Erduran ve Kabaş, 2010). Böylelikle Çanakkale kenti için uygun bitkiler kullanılmıştır.

Parkta bulunan bitki türlerinin birçoğu Calvert ailesinin konağından kalmıştır ve Cupressus sempervirens L., Pinus brutia L., Ulmus campestris L. gibi türler 1930'lu yıllardan beri korunmaktadır (URL 4, 2008; Erduran ve Kabaş, 2010).

Çanakkale Halk Bahçesi konumu, ulaşım kolaylığı ve kentsel alandaki önemi sebebi ile kullanıcılar tarafından çok tercih edilmektedir. Alan 2017 yılının Ağustos-Eylül aylarında modern kentsel peyzaj uygulamalarına göre revize edilmiş̧ir. Alanda yaya aksları, girişler, spor ve çocuk oyun alanları, tuvaletler gibi birçok öğe halkın fonksiyonel kullanımı için yeniden tasarlanmıştır (URL 6, 2018).

Çalışma alanında geniş yapraklı ağaçlı yollar, süs bitkileri, renkli çalı ve ağaççklar bulunmaktadır. Farklı zemin döşemelerine yer verilmiştir. Alana ilk bakıldığında hâkim bitkisel doku göze çarpmaktadır. Yüksek kullanım potansiyeline sahip olan bu kamusal mekân kentin doğal hareket alanı haline gelmiştir. Pergola, taş yol, havuz gibi kent plastiği açısından birçok peyzaj elemanlarına yer verilen alan revize edilmiş hali ile kent kullanıcılarının dinleme, eğlenme, gezinme vb. rekreasyonel aktivitelerini karşılamaktadır. Mevcut yapıda kullanıcılar için spor alanı, yaya aksları, çocuk oyun alanları, kafe, amfi ve tuvaletler bulunmaktadır.

Kullanıcıların oksijen ihtiyacını, bitkisel alana olan özlemlerini gideren alanda birçok aktivite alanı ile birlikte dinlenme alanları da bulunmaktadır (Sağlık vd., 2020) (Şekil 5). Çanakkale Halk Bahçesi'nin herkes için tasarım ilkeleri açısından kullanımlarının değerlendirilmesi aşağıdaki başlıklar altında detaylandırılmıştır. 


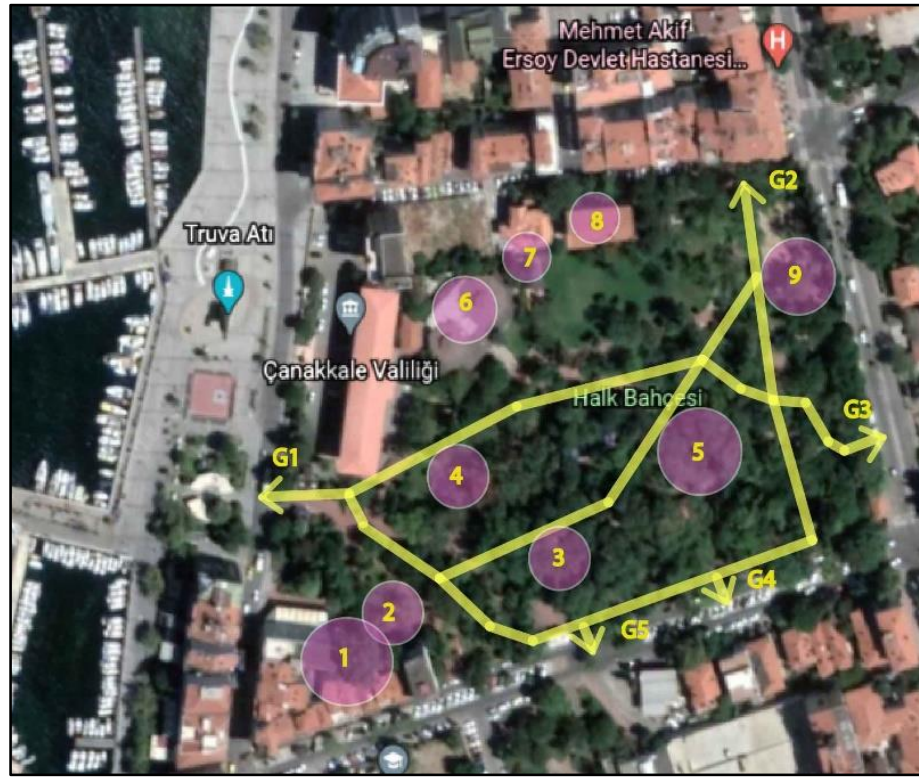

1 ve 6 - Kafeterya 2- Hayvan Barınağı 3- Hayvan Parkuru 4- Amfi 5-Spor Alanı 7- Bakkal 8-Tuvaletler 9- Çocuk Oyun Alanı

\section{Girișler}

Şekil 5. Alan kullanımları (Google Earth 2021).

Alana dört bir yandan giriş mevcuttur. Alanda 5 adet giriş kapısı vardır ve bu kapılarla beraber Muammer Aksoy Parkı'na, Eski Kordon'a, Cumhuriyet Meydanı'na ve kent çarşısına çıkılmaktadır. Aynı zamanda İskele Meydanı’na da erişim sağlanmaktadır. Halk Bahçesi kent içinde geçiş noktası niteliği taşımaktadır. Motorlu taşıtların alana erişimi kısıtlanmıştır. Ayrıca tekerlekli sandalye kullanan bireylerin alana erişimi için rampa bulunmamaktadır (Şekil 6).
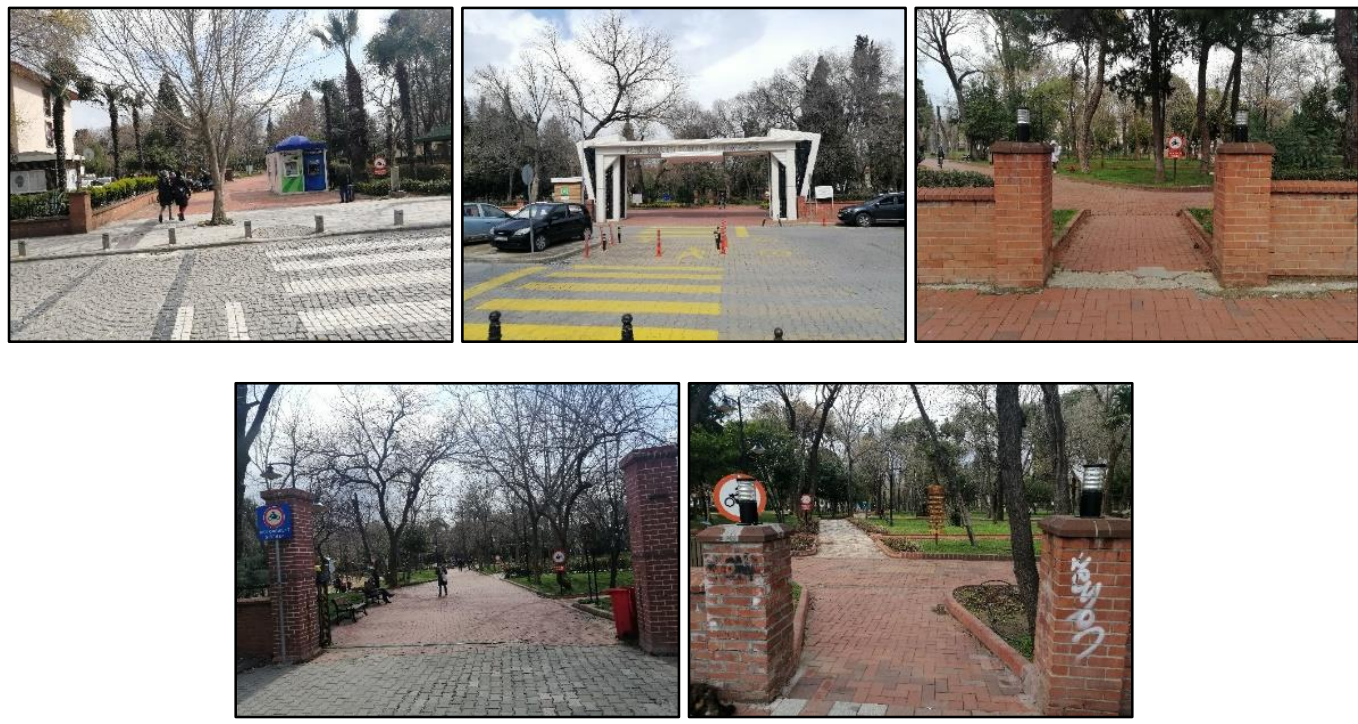

Şekil 6. Çalışma alanına ait girişler (Orijinal, 2021).

\section{Heykel ve plastik objeler}

Alanda 4 adet heykel bulunmaktadır. Mevcut heykeller çim zemin üzerine konumlandırılmıştır. Zemin dokusunun uygun olmaması sebebi ile engelli bireylerin erişimi kısıtlı olsa da çocuklar heykellere erişebilmektedir. İçlerinde en göze çarpan Zübeyde Hanım heykelidir. Ayrıca aynı isimde ve heykelin karşısında bulunan giriş kapısı mevcuttur (Şekil 7). 

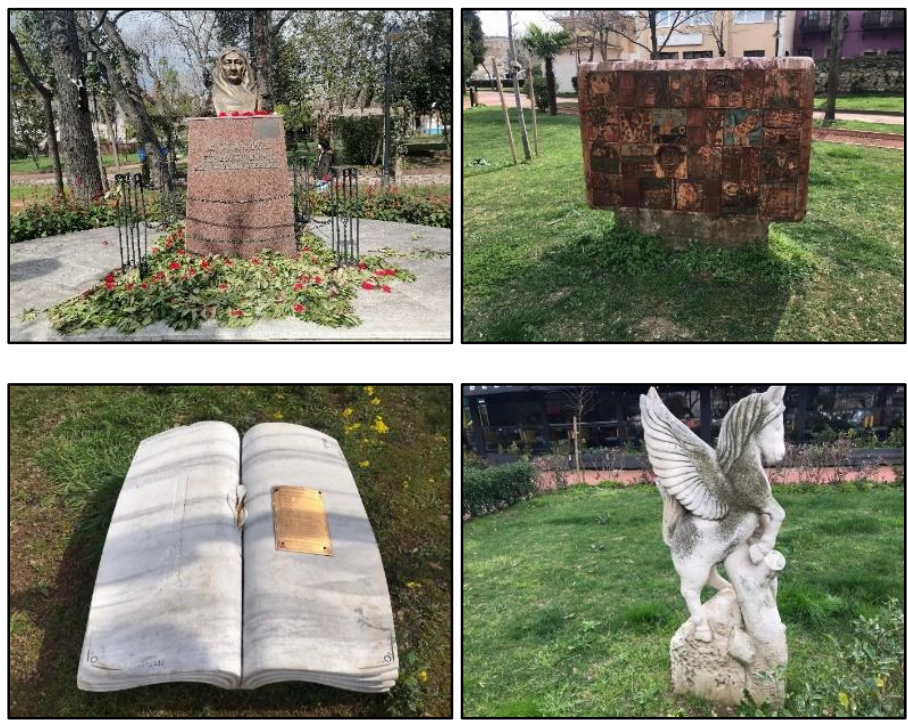

Şekil 7. Çalışma alanındaki heykel ve plastik objeler (Orijinal, 2021).

\section{Spor alant}

Alanda çocuk, yetişkin ve engelli bireyler için 3 farklı türde açık spor aleti kullanılmıştır. Spor aletleri engelli bireylerin kullanımına uygun olsa da alana erişim sağlanamamaktadır. Yürüyüş yolu ile spor alanı arasında kot farkı olmasına rağmen rampa bulunmamaktadır (Şekil 8).
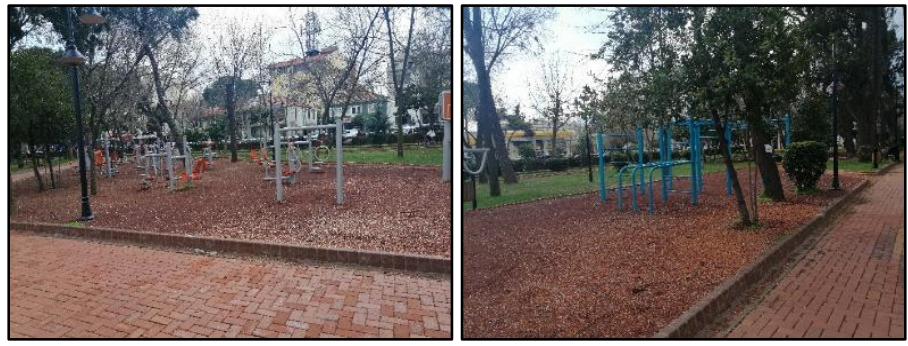

Şekil 8. Çalışma alanındaki spor alanı (Orijinal, 2021).

\section{Bilgilendirme panolart}

Çalışma alanı kent içindeki acil durum toplanma alanlarından en büyüğüdür. Alanda genel kurallar kapsamında birçok bilgilendirme ve yönlendirme panoları bulunmaktadır. Bunlar alan içinde sirkülasyonu sağlamaktadır. Görme engelli bireyler için sesli uyarı sistemi bulunmayan panolar renkli ve farklı kullanımları ile algılanabilir durumdadır (Şekil 9).
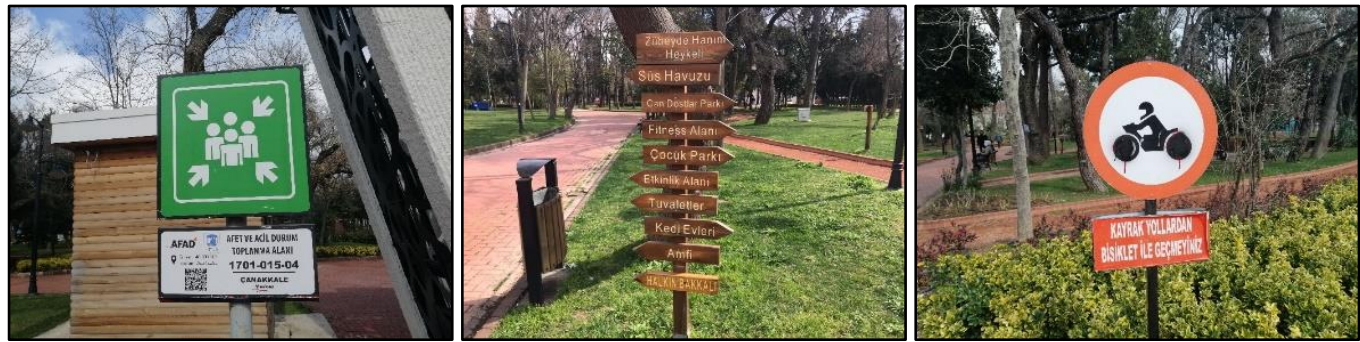

Şekil 9. Çalışma alanındaki başlıca bilgilendirme panoları (Orijinal, 2021).

\section{Oturma birimleri}

Alanda 3 farklı oturma birimi mevcuttur. Yaya aksları boyunca modernize edilmiş banklar bulunmaktadır. Ayrıca çocuk oyun alanında taş döküm üzerine oturma birimi yerleştirilmiştir. Alanın kuzeybatısında ise toplu 
oturma birimleri mevcuttur. Mevcutta bulunan 3 farklı oturma biriminin de zeminle arasinda kot fark1 bulunmasına rağmen engelli bireylerin erişimini sağlayan rampalar bulunmamaktadır (Şekil 10).
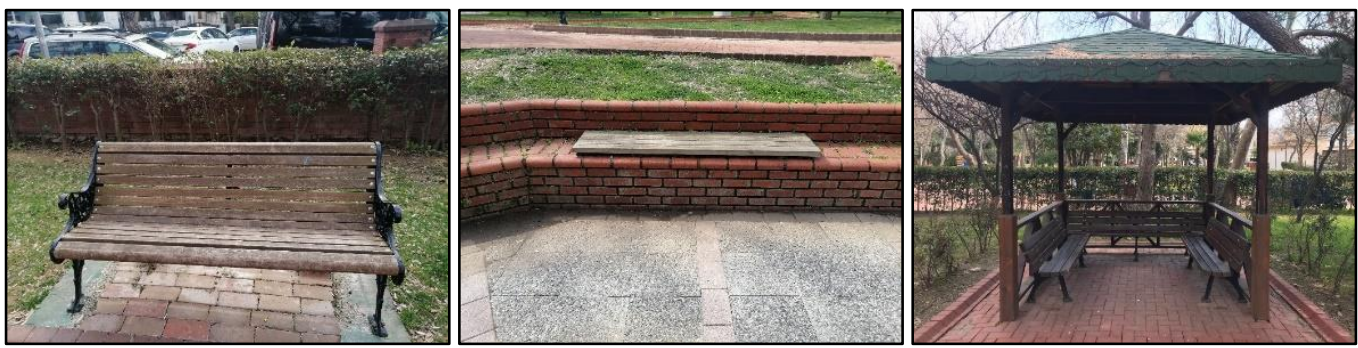

Şekil 10. Çalışma alanında bulunan oturma birimleri (Orijinal, 2021).

\section{Havuz ve yakın çevresi}

Havuz alanına erişim merdivenlerle sağlanmaktadır ve rampa bulunmamaktadır. Bu da herkesin alana erişimini kısıtlamaktadır. Fıskiye ve renkli 1şıklarla alanda hareketlilik sağlanmaktadır. Havuzu çevreleyen banklar bulunmaktadır (Şekil 11).
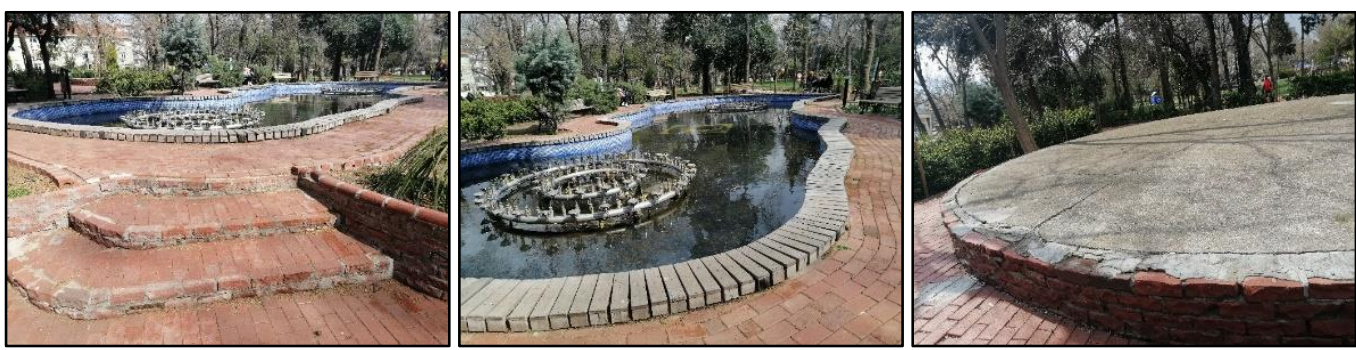

Şekil 11. Çalışma alanındaki havuz (Orijinal, 2021).

\section{Hayvan barınăğ ve eğitim alanı}

Alanda kedi, köpek ve kuşlar için barınma alanları mevcuttur. Ayrıca hayvanlar için koşu parkuru bulunmaktadır (Şekil 12).
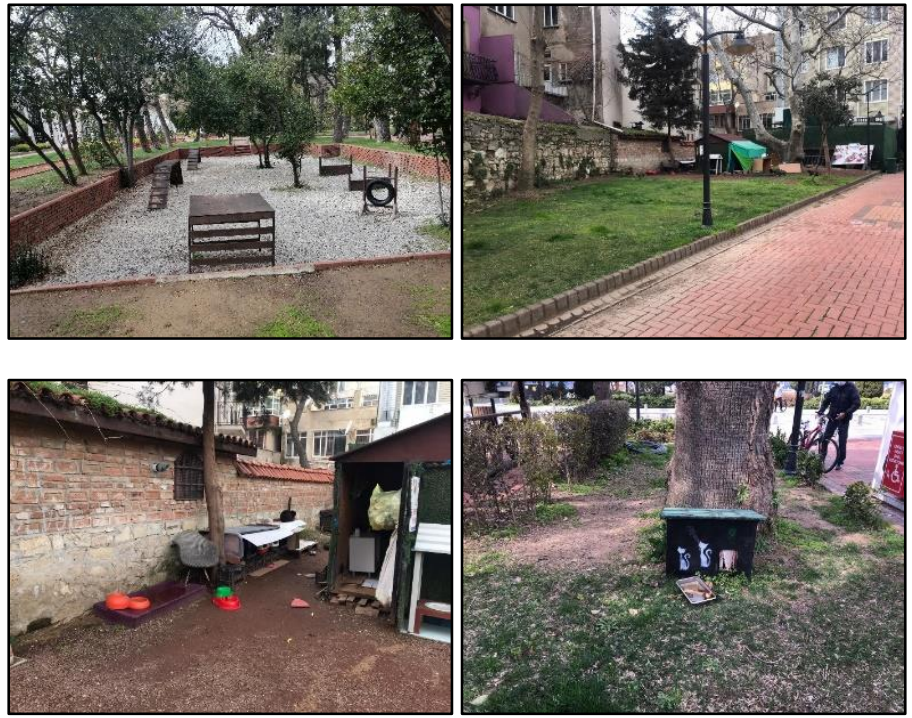

Şekil 12. Çalışma alanındaki hayvan barınağı ve eğitim alanı (Orijinal, 2021).

\section{Zemin özellikleri}

Alanda beton parke taşı, kauçuk, kayrak taşı, kum ve kiremit irmiği gibi birçok farklı zemin malzemesi kullanılmıştır. Çocuk oyun alanları ve koşu parkuru için yumuşak zemin tercih edilmiştir. Yürüyüş yolu, spor alanı, koşu parkuru gibi alanlarda kullanılan zeminler olumsuz hava koşullarında engelli bireylerin kullanımına 
imkan sağlamaktadır. Fakat çocuk oyun alanında kullanılan kum zemin yağmurlu havaya uygun olmamakla beraber tekerlekli sandalye kullanan bireylerin erişimini kısıtlamaktadır. Alandaki kayrak taşl1 yol $440 \mathrm{~m} 2$ ve kiremit irmiği koşu parkuru 510 metre uzunluğundadır. Ayrıca zemin ayrımları genellikle bordür ve oluklarla olmaktadır (Şekil 13).
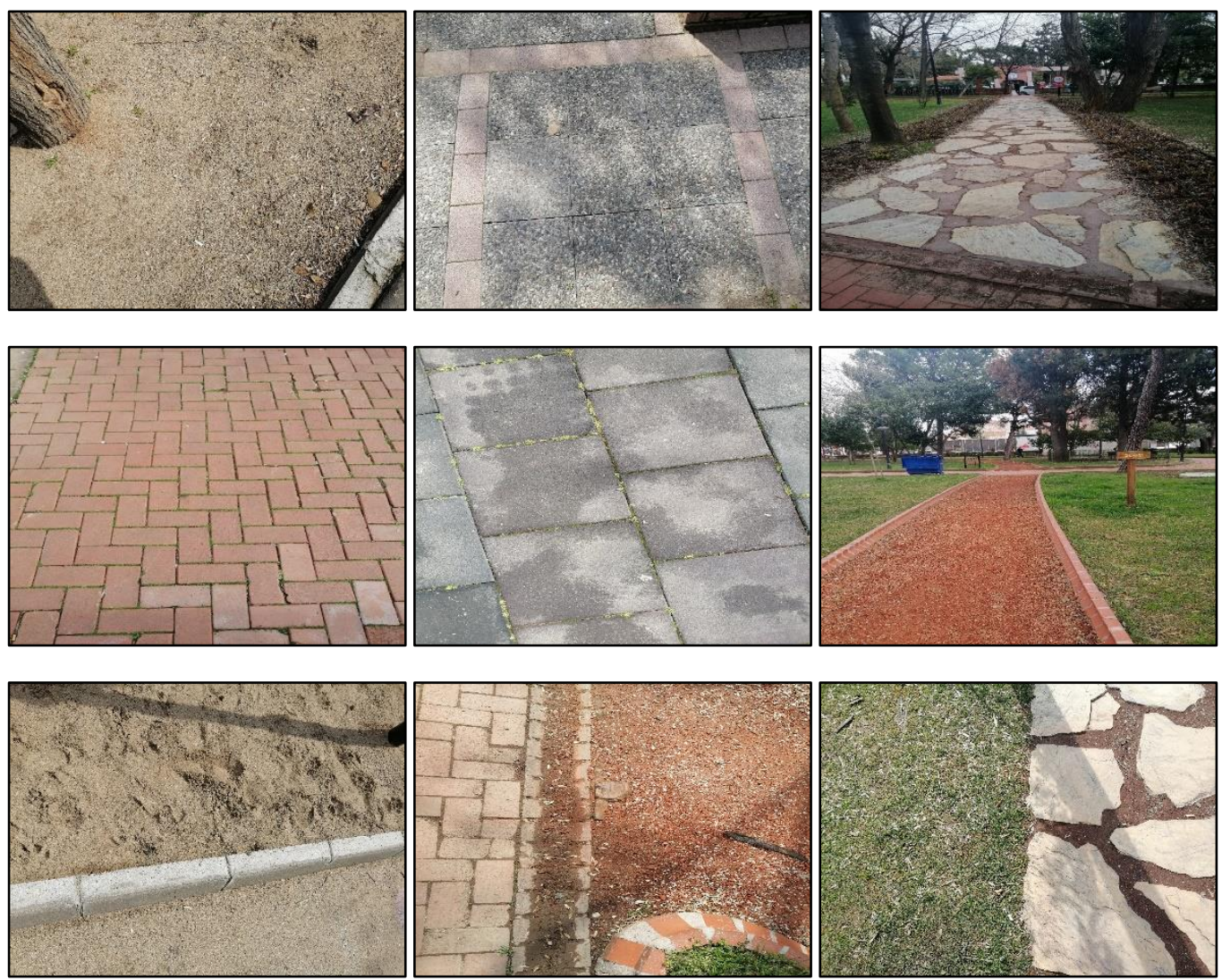

Şekil 13. Çalışma alanındaki zemin kaplamaları ve zemin ayrımları (Orijinal, 2021).

\section{Bitkisel doku}

Alanda benzer türden bitkilere sıklıkla rastlanmaktadır. Bu da tasarımda monotonluğa sebebiyet vererek algılanabilirliği düşürmektedir. Ayrıca soliter olarak kullanılan ağaçlar bordürle sınırlandırılmaktadır. Böylelikle alan içindeki erişim kolaylaştırılmıştır (Şekil 14).
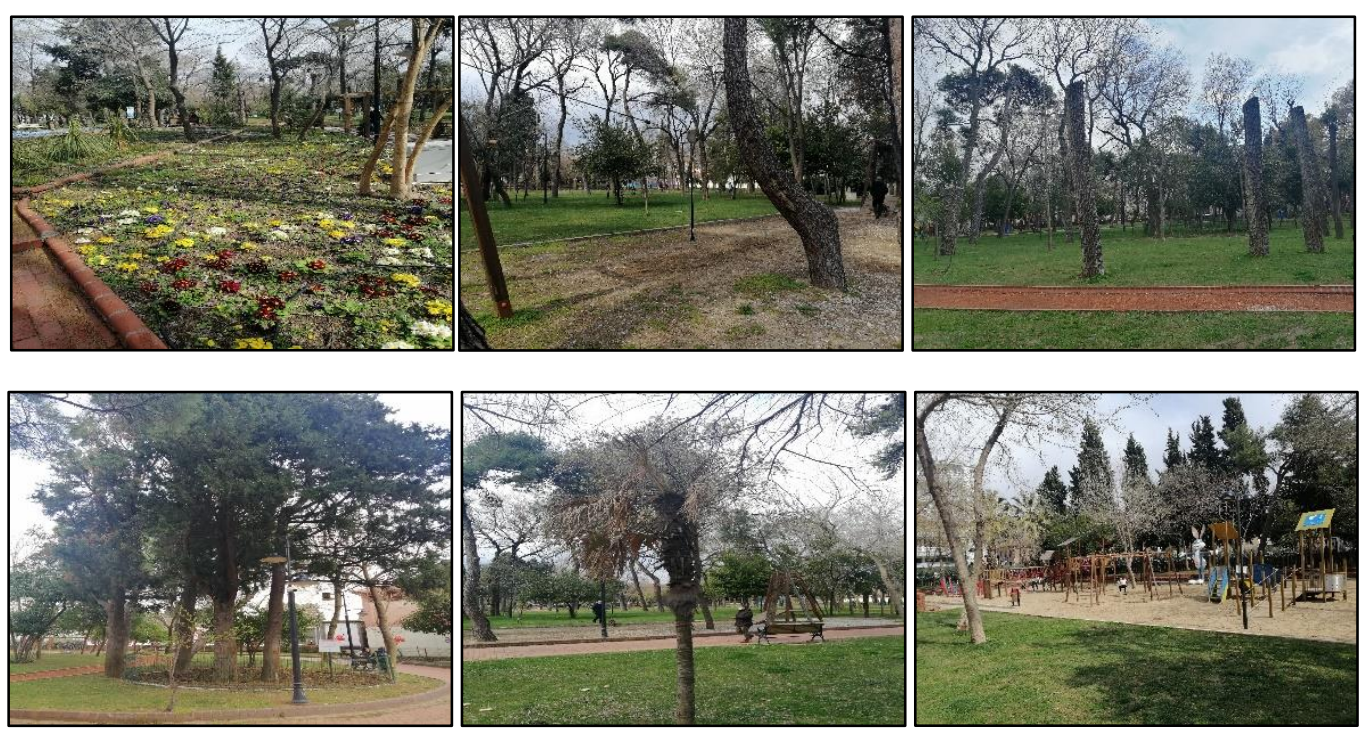

Şekil 14. Çalışma alanındaki bitkisel doku (Orijinal, 2021). 


\section{Yapısal ve çevresel elemanlar}

Alanda kullanılmayan bir güvenlik kulübesi, kafe, büfe, çeşme ve tuvalet bulunmaktadır. Alanın yakın çevresinde kafe, Valilik binası ve işletmeler mevcuttur ve Şekil 15’te gösterilmektedir. Bu kullanımlarda dezavantajlı kullanıcılar için ekstra bir tasarım yapılmamıştır. Alan içinde bulunan kafede merdivenin yanına rampa eklenmiştir. Fakat rampanın tasarım ve planlama sürecinden sonra eklenmesi, eğiminin ve genişliğinin engelli bireylerin kullanımına uygun olmadığı tespit edilmiştir.
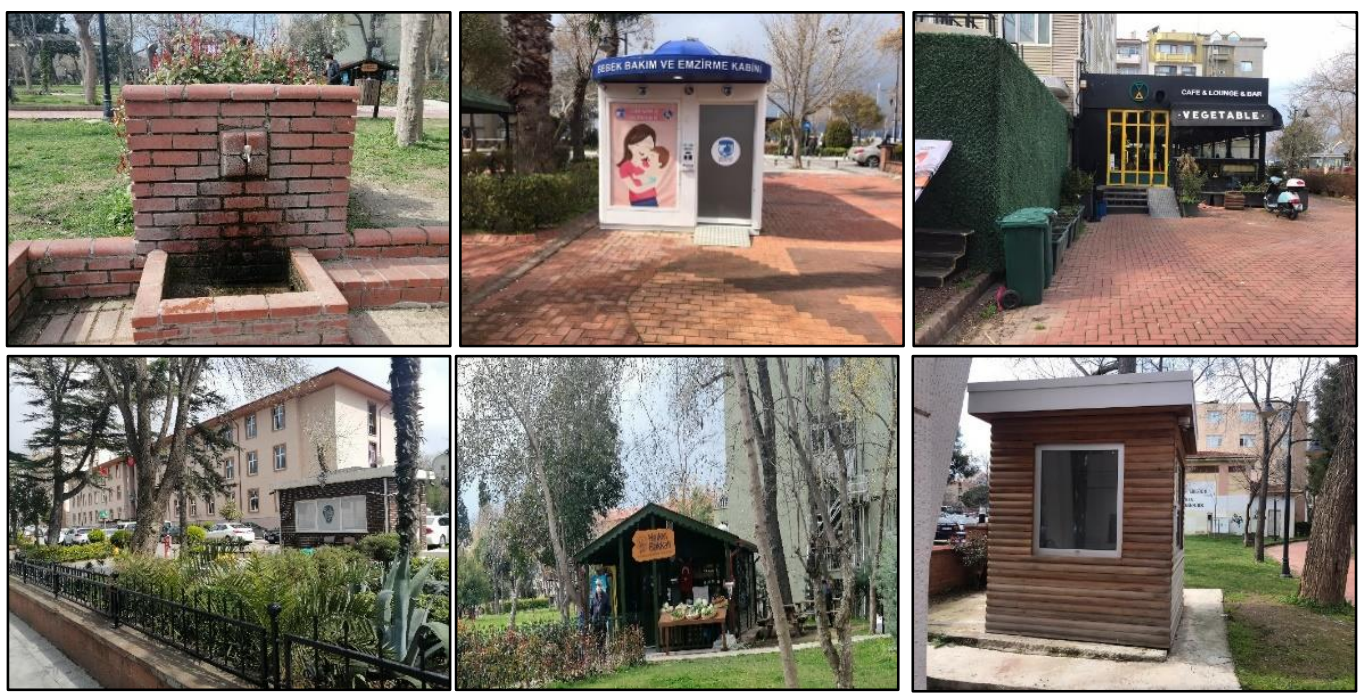

Şekil 15. Çalışma alanındaki yapısal ve çevresel elemanlar (Orijinal, 2021).

\section{Amfi tiyatro}

Yuvarlak formda bulunan amfi toplu oturma alanı sağlamakta, özellikle gençler için bir buluşma ve etkinlik alanı olmaktadır. Yapı malzemesi olarak beton üzerine ahşap materyal tercih edilmiştir. Bunlara ek olarak alana görme engeli bulunan bireylerin erişimi için iz takibi ve yol boyu tekerlekli sandalye kullanan bireyler için yeterli eğim imkânı sağlanmıştır (Şekil 16).
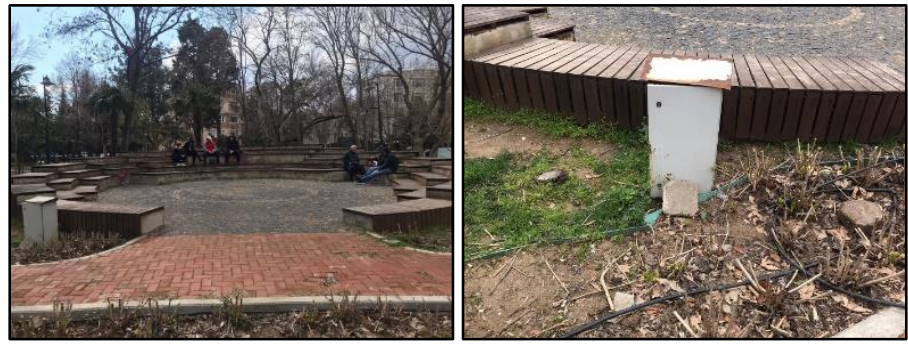

Şekil 16. Çalışma alanındaki amfi tiyatro (Orijinal, 2021).

\section{Sintrlayıcı elemanlar}

Alanı duvarlar, bordürler ve demir korkuluklar sınırlandırmaktadır. Ayrıca sınır duvarlarını örtmek için çit bitkileri tercih edilmiştir. Bu sınırlayıcı elemanlar ile alana kontrollü erişilebilirlik sağlanmaktadır (Şekil 17).
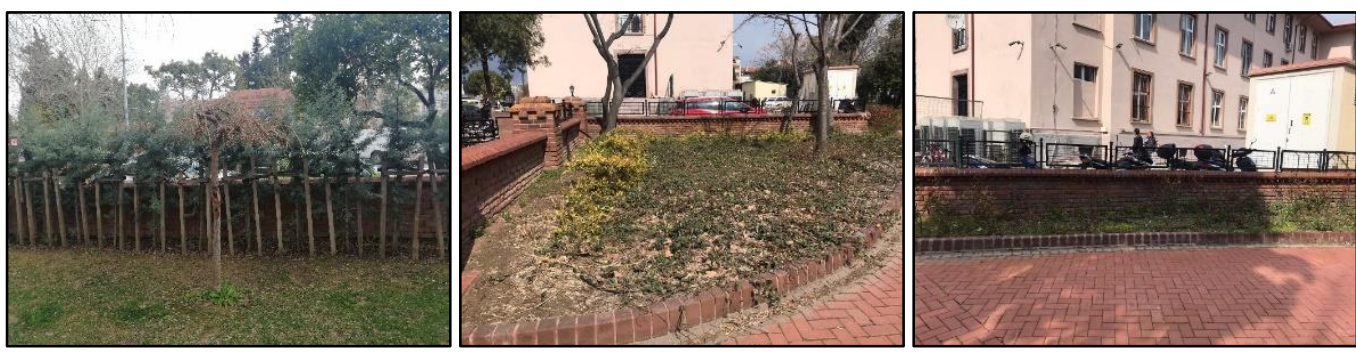

Şekil 17. Çalışma alanındaki sınırlayıcı elemanlar (Orijinal, 2021). 


\section{Çocuk oyun alanı}

Çocuk oyun alanı kum ve kauçuk zemine konumlandırılmıştır. Oyun donatıları birçok yaş grubuna uygundur ve yoğun kullanımı karşılayabilecek kapasitededir. Fakat farklı engellilik durumu bulunan çocuklar için uygun zemin ve oyun donatıları mevcut değildir (Şekil 18).
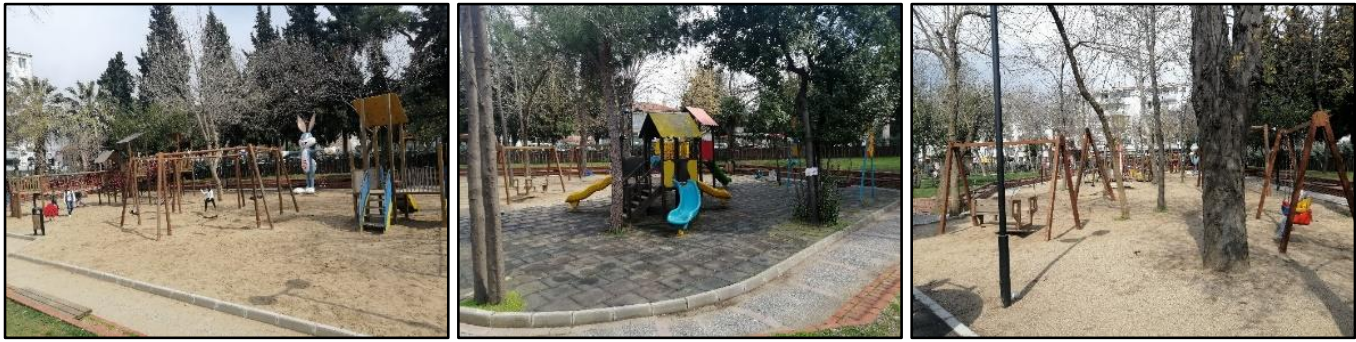

Şekil 18. Çalışma alanında bulunan çocuk oyun alanları (Orijinal, 2021).

\section{Çöp kutuları}

Alanda ahşap çöp kutusu bulunmaktadır. Ayrıca belli noktalarda plastik konteynerler mevcuttur (Şekil 19).
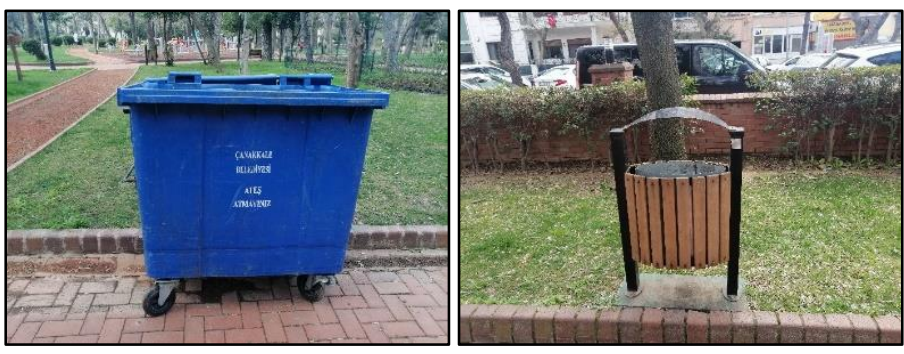

Şekil 19. Çalışma alanındaki çöp kutuları (Orijinal, 2021).

\section{Aydınlatma elemanlart}

Yaya aksları boyunca tek tip yüksek aydınlatma ve sınır duvarları üzerinde bodur aydınlatmalar bulunmaktadır (Șekil 20).
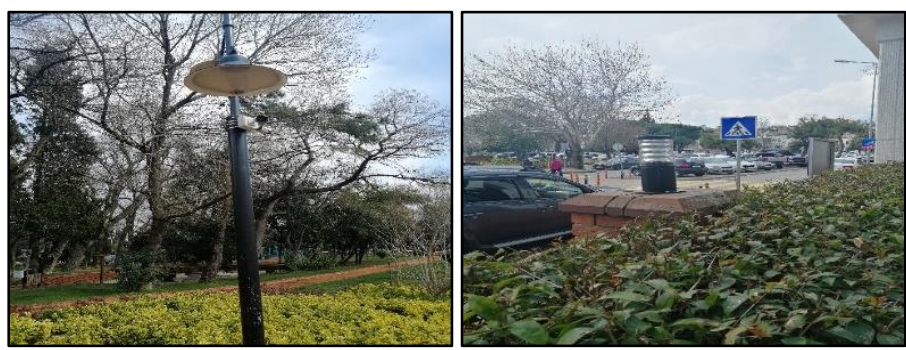

Şekil 20. Çalışma alanındaki aydınlatmalar (Orijinal, 2021).

\section{Sonuç ve Öneriler}

Kentsel alanların dezavantajlı kullanıcılar tarafından da kullanımının sağlanması için çalışmada herkes için tasarım ilkeleri kapsamında alan kullanımlarına yönelik çözüm önerileri geliştirilmiştir. Çalışmada yol gösterici olması sebebiyle Evrensel Tasarım Merkezi (The Center for Universal Design) tarafindan belirlenen 7 ilke ışığında çalışma alanına ait yapısal ve çevresel elemanlar irdelenmiş̦tir. Türk Standartları Enstitüsü (TSE)' nün belirlediği ilkelerden yararlanan Hatipoğlu (2017), Demirci (2020), İmren ve Kiper (2020)'in çalışmaları kapsamında alan sınıflandırılarak değerlendirilmiştir;

- Alan girişlerinde görme engelli bireyler için iz takibi, tekerlekli sandalye kullanan bireyler için de yeterli açıklık ve rampa bulunmamaktadır. Girişlerde bulunan sınırlayıcı elemanlar yeterli genişlikte yeniden konumlandırılmalı ve rampa eklenmelidir. Ayrıca sadece girişlere değil park içine de görme engelli bireyler için farklı zemin dokusu ile iz takibi sağlanmalıdır. 
- Alan içinde maksimum eğim \%2’yi geçmemelidir. Alandaki yaya yollarında herhangi bir eğim bulunmaması olumludur. Mevcut yaya aksı tüm kullanıcılar için uygundur. Böylelikle düşük fiziksel çaba ilkesi sağlanmıştır.

- Yaya yolları materyali kaymayı engellemeli ve yaya akslarında bulunan rögar kapakları zeminle aynı kotta olmalıdır. Alanda kilit parke taşı kullanılmıştır ve zemin kaygan değildir. Ayrıca aksların düzenli onarımı yapıldığı için dezavantajlı grupların kullanımına elverişlidir. Mevcut rögar kapakları zeminle aynı kotta olmakla beraber yaya yolları üzerinde bulunan bitkiler bordürle sınırlandırılmıştır. Böylelikle alan kullanımı tüm kullanıcılar için kolaylaşmıştır ve eşit kullanım ilkesi bu açıdan sağlanmıştır.

- Kullanılan rampaların zemininde sert, kaymaz ve az pürüzlü malzeme tercih edilmelidir. Ayrıca rampaların başında ve sonunda görme engelli bireylerin kullanımına uygun 1,5 m uzunluğunda, farklı dokulu alanlar bulunmalıdır. Çalışma alanı yaya aksı düz ve düze yakın olduğu için rampaya gerek duyulmamıştır. Çocuk oyun alanı gibi kullanımlar yaya aksından düşük kotta bulunmaktadır. Fakat alana erişim merdivenle sağlanmaktadır. Mevcut alanlara standartlara uygun rampa eklenerek yaklaşım ve kullanım için boyut ve mekân ilkesi sağlanmalıdır.

- Engelli bireyler için genişliği en az 3,6 m olan otoparklar konumlandırılmadır ve bunların sayısı mevcut park yeri sayısının \%5'i kadar olmalıdır. Alanın yakın çevresinde ve alanı çevreleyen yol kenarı otoparkları mevcuttur. Fakat hiçbirinde ayırıcı şeritler ve engelli bireyler için özel alan bulunmamaktadır. Otoparkların planlaması tüm kullanıcıların gereksinimleri esas alınarak yeniden yapılmalı ve gerekli ölçüler 1şığında zemin üzerine ayırıcı şeritlerle mekânın fark edilebilirliği arttırılarak algılanabilir bilgi ilkesi sağlanmalıdır.

- Oturma birimlerinin yerden yüksekliği $45 \mathrm{~cm}$, sırt yaslama yerinin yüksekliği $70 \mathrm{~cm}$ olmalıdır. Bankların yakın çevresinde tekerlekli sandalye kullanan bireyler için $120 \mathrm{~cm}$ genişliğinde hareket alanı bulunmalıdır. Alan içinde yaya aksını takip eden banklar bulunmaktadır. Bank ölçüleri standartlara uygundur ve yaya aksından cepler çıkartılarak konumlandırılmıştır. Böylelikle yaya hareketi kısıtlanmamıştır. Fakat banklar yaya yollarından $15 \mathrm{~cm}$ üst kotta yeşil alana konumlandırılmıştır. Alan çevresinde tekerlekli sandalye kullanan bireyler için hareket alanı ve rampa bulunmamaktadır. Uygulanan tasarım her kullanıcı için işlevsel olmadığı için dezavantajlı kullanıcılara yönelik güncel alternatifler düşünülmelidir. Böylelikle kullanımda esneklik ilkesi sağlanmalıdır.

- İşaret ve yönlendirme levhaları ayırt edici renkte ve minimum $70 \mathrm{~cm}$ yükseklikte olmalıdır. Levhalarda uluslararası semboller kullanılmalıdır. Alan içindeki levhalar yeterli bilgilendirmeyi sağlamaktadır. Ayrıca yükseklikleri kullanıcıların göz seviyesinde olması kullanım zorluğu yaşatmamaktadır. Alan içindeki levhalar tercih edilen renkleri itibarıyla fark edilebilir niteliktedir. Fakat görme yetisi zayıf ve görme engelli bireyler için uygun formda ve dokuda değillerdir. Bu yüzden alan içindeki levhalar farklı kullanıcı grupları düşünülerek yeniden düzenlenmeli ve algılanabilir bilgi ilkesi sağlanmalıdır.

- Aydınlatmalar yeterli sayı ve nitelikte kullanılmalıdır. Alan içinde mahremiyeti, güvenliği ve erişimi sağlayacak yeterli sayıda aydınlatma elemanı bulunmamaktadır. Taşıma kapasitesi düşünülerek yeni yüksek aydınlatmalar alan içinde konumlandırılmalıdır. Böylelikle basit ve sezgisel kullanım ilkesi sağlanmalıdır.

- Yüksek ısıdan etkilenmeyen farklı renkte ve kullanımı kolay çöp kutuları tercih edilmelidir. Alana kullanıcıların erişebileceği yükseklikte, farklı doku ve renkte, olumsuz çevre koşullarına dayanıklı yeterli sayıda çöp kutusu konumlandırılmalı. Böylelikle hatalara dayanım ilkesi sağlanmalıdır.

- Kent parkı içinde bulunan mevcut kullanımlarda kot farkı varsa merdiven dışında dezavantajlı kullanıcılar için rampa da bulunmalıdır. Alanda çocuk oyun alanlarına erişim merdivenle sağlanmıştır. Engelli bireyler için uygun rampa bulunmamaktadır. Oyun elemanları engelli çocuklarının kullanımına uygun değildir. Tercih edilen zemin sert ve hafif pürüzlü olmadığı için engelli bireylere yönelik değildir. Mesleğinde uzman peyzaj mimarları 1şı̆̆ında alan için yeni ve standartlara uygun plan kararları alınmalıdır.

- Alanda çocuk, yetişkin ve engelli bireyler için 3 farklı türde açık spor aleti kullanılmıştır. Fakat spor alanı yaya aksından $15 \mathrm{~cm}$ yükseklikte bulunmaktadır. Tüm kullanıcıların erişimi için standartlara uygun rampa tasarlanmalidir.

Kentsel diş mekanlarda herkes için tasarım kapsamında örnekler literatür taraması yapılarak incelenmiştir. Çanakkale'deki mevcut kent parkının durum tespiti yapılmış ve eksiklikleri saptanmıştır. Bu çalışmada, kentsel dış mekânların Evrensel Tasarım Merkezi tarafından belirlenen 7 ilke doğrultusunda tüm kullanıcılar dâhilinde işlevsel kullanımı göz önüne alınarak TSE’nin standartları kapsamında alana dair herkesin kullanımına uygun çözüm önerileri geliştirilmiştir.

Sonuç olarak; kentsel açık yeşil alanların planlanması ve tasarlanması sürecinde estetiksel niteliklerin yanı sıra fonksiyonellik ve ergonomi de herkes için tasarım kapsamında ele alınmalıdır. Elde edilen veriler 1şığında Çanakkale kent merkezinde en sık kullanılan açık yeşil alanın Halk Bahçesi olduğu belirlenmiştir. Alanın konumu gereği ulaşılabilir olmasına karşın kentlinin kısıtlı erişim imkânı olduğu saptanmıştır. Aktif kullanılan kent parkının herkesin erişimine ve kullanımına uygunluğu irdelenmiş ve Evrensel Tasarım İlkeleri’ne uygun koşulların sağlanması gerektiği vurgulanmıştır. 


\section{Kaynaklar}

1. Çelik, Ö. (2013). Mekânsal Planlama ve Tasarım Sürecinde "Engellilik.” Yüksek Lisans Tezi. İstanbul Teknik Üniversitesi Fen Bilimleri Enstitüsü, Şehir ve Bölge Planlaması Anabilim Dalı, İstanbul, 5-53 s.

2. Çenet, S. (2013). Tarihi Kent Merkezinin Herkes İçin Tasarım İlkeleri Açısından İncelenmesi; Edirne Örneği. Yüksek Lisans Tezi. Beykent Üniversitesi Fen Bilimleri Enstitüsü, Mimarlık Anabilim Dalı, İstanbul, 3-28 s.

3. Çetin, G. (2003). Üsküdar İlçesi'ndeki Çocuk Oyun Alanlarının Yeterlilik ve Kalite Açısından İncelenmesi. Yüksek Lisans Tezi. İstanbul Teknik Üniversitesi Fen Bilimleri Enstitüsü, Şehir ve Bölge Planlaması Anabilim Dalı, İstanbul, 2-16 s.

4. Demirci, A. (2020). Erişilebilirliğe Yönelik Engelsiz Yaşam Merkezi Tasarım Yaklaşımları: Etimesgut Belediyesi Engelsiz Yaşam Merkezi Örneği. Yüksek Lisans Tezi. Başkent Üniversitesi Sosyal Bilimler Enstitüsü, İç Mimarlık ve Çevre Tasarımı Ana Bilim Dalı, Ankara, 24-89 s.

5. Erduran, F., Kabaş S. (2010). Parklarda Ekolojik Koşullarla Dengeli, İşlevsel ve Estetik Bitkilendirme İlkelerinin Çanakkale Halk Bahçesi Örneğinde İrdelenmesi. ÇEV-KOR, 190-199.

6. Erduran, F. Akdeniz, F., Çayamaz, R. (2018). Evrensel Erişilebilir Çocuk Parkı Tasarımı: Çanakkale Kepez Örneği. Uluslararası Peyzaj Mimarlı̆̆ı Araştırmaları Dergisi, 2(2): 08-14. Online ISSN: 26024322.

7. Hatipoğlu, M.K. (2017). Ankara - Çayyolu - Ahmet Taner Kışlalı Mahallesi’nin Evrensel Tasarım İlkeleri Bağlamında İncelenmesi. Yüksek Lisans Tezi. Ankara Üniversitesi Fen Bilimleri Enstitüsü, Peyzaj Mimarlı̆̆ Anabilim Dalı, Ankara, 88-138 s.

8. Kuter, N., Çakmak, M. (2017). Kamusal Dış Mekânlarda Engelliler İçin Tasarım: Ankara, Seğmenler Parkı Örneği. Anadolu Orman Araştırmaları Dergisi, 3(2) 93-110.

9. Sağlık, A., Alkan, Y., Kelkit, A., Çavuşoğlu, G., Sağlık E. (2016). Peyzaj Mimarlığında Fonksiyonel Mekan Çözümlemesine Yönelik Bir Tasarım Çalışması. Uluslararası Hakemli Tasarım ve Mimarlık Dergisi. 09- Sonabhar Kıș Dönemi: 97-110. Online ISSN: 2148-4880

10. Sağlık, A., Baytan, N., Bayrak, M.İ., Temiz, M., Kelkit, A. (2020). Çanakkale Halk Bahçesi’ndeki Aydınlatma Donatılarının Enerji Verimliliği Açısından Optimizasyonu. Kent Kültürü ve Yönetimi Dergisi. 13(4): 599-608. Online ISSN: 2146-9229.

11. Ergenoğlu, A. (2013). Mimarlıkta Kapsayıcılık: 'Herkes İçin Tasarım'. Yıldız Teknik Üniversitesi Mimarlık Fakültesi Ders Notu, İstanbul, 24-35 s.

12. İmren, Ö., Kiper, T. (2020). İstanbul Çırpıcı Kent Parkı'nın Engelli Kullanımı Açısından Değerlendirilmesi. Iğdır Üniversitesi Fen Bilimleri Enstitüsü Dergisi, 10(3): 2062-2075. Online ISSN: 2146-0574.

13. URL-1 (2015). https://www.plantdergisi.com/doc-dr-gul-en-aytac/kent-parklari-4.html, Plant Peyzaj ve Süs Bitkiciliği Dergisi, (13.04.2021).

14. URL-2 (2021). https://tr.wikipedia.org/wiki/\%C3\%87anakkale, (20.03.2021).

15. URL-3 (2020). https://www.lafsozluk.com/2012/01/canakkale-ilinin-turkiye-haritasindaki.html, (20.03.2021).

16. URL-4 (2008). https://www.canakkaleili.com/canakkale-halk-bahcesi.html, Çanakkale Merkezi Değerleri Sempozyumu, (20.03.2021).

17. URL-5 (2012). https://www.comuhaber.com/2012/06/08/canakkale-kent-tarihi-ve-halk-bahcesi/, Çomü Haber, (20.03.2021).

18. URL-6 (2018). https://www.canakkale.bel.tr/file/262/V2rfPumlsDOqxoebfW3ANpKABTVToW_k.pdf, Çanakkale Belediyesi, Halk Bahçesi Yenileme Yapım İşi, (20.03.2021).

19. Ünal, M. (2009). Çocuk Gelişiminde Oyun Alanlarının Yeri ve Önemi. İnönü Üniversitesi Ĕ̆itim Fakültesi Dergisi, 10(2): 95-109. Online ISSN: 1300-2899. 